\title{
Korean Private Higher Education Faces Economic Crisis
}

\section{Sungho H. Lee}

Sungho H. Lee is professor and dean, College of Education, Yonsei University, Seoul Korea. He has served as assistant minister for higher education in the government of Korea. Address: School of Education, Yonsei University, 134 Sinchon-dong, Sodaemon-ku, Seoul 120-749 Korea.

$I^{n}$ Korea, private four-year colleges and universities outnumber by far the public ones, enrolling more than three-quarters of all students. No one can deny that, for the past half century, the private institutions of higher education in Korea have made a considerable contribution to the economic, social, and cultural development of the nation. However, many private institutions are today faced with such serious problems as financial constraints and a degrading of the quality of education. These problems became even more pressing since December 1997, with the beginning of the nation's economic crisis and the relief loan from International Monetary Fund.

From the outset, private colleges and universities in Korea have depended mainly on student tuition fees in their financial management. At present, the tuition fees make up on average 63.2 percent of the entire finances of private institutions. However, it is well known that many institutions depend for more than 95 percent of their finances on tuition revenues. In particular, private institutions located in provincial areas have had the hardest time with tuition-based financing. Many students, more than 30 percent in some institutions, have dropped out to transfer to institutions in the Seoul metropolitan area.

Government financial support for private institutions dates back only a few years. In 1990, for the first time, the government appropriated financial support for private four-year institutions- 0.29 percent of the entire education budget. In 1997, this was raised to 0.76 percent, but this was provided disproportionately. About 54 percent of the government appropriation was offered to the top 10 institutions among the 124 private institutions. In Korea, most institutions of private higher education have no profit-making enterprises. Only a few universities, such as Yonsei and Hanyang, raise funds from building leases and other proprietary business activities.

On the other hand, endowment to private institutions has not been successful. Each and every private institution has desperately sought donations. A few top-level elite institutions have had some success in collecting contributions from their alumni and major corporations, but with the so called "IMF cri- sis" such contributions were suspended. Some private institutions obtained a multitude of foreign and domestic loans, which further aggravated their financial difficulties due to the devaluation of the Korean currency and the higher interest rates charged by domestic banks.

In sum, all the above-mentioned restraints have driven private institutions in Korea into financial crisis. At present, more than one-third of private institutions are deeply in debt, being liable for more than U.S.\$14 million. Indeed, in March 1998, one large private comprehensive university located in Seoul went into bankruptcy, and some other institutions are now rumored to be on the brink of insolvency. In July 1998, the government, which has sole authority over the establishment of higher education institutions, permanently shut down two private fouryear institutions because of financial deficiency and poor academic management.

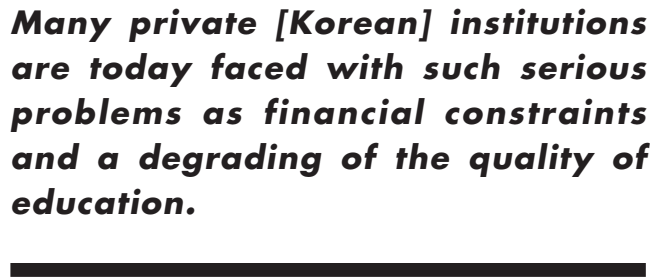

Faced with such imperatives, both government and the private institutions are now considering all possible countermeasures. For example, the government has urged four-year colleges and universities to combine academic departments into larger divisions under the veil of education reform and with the bait of government financial support as a reward. And, each institution is asked to establish its unique character, in terms of structure, management, and curriculum. Along with such restructuring of internal academic administration, some comprehensive universities are now being encouraged to establish new professional graduate schools in such major fields as medicine, engineering, business administration, public administration, education, and law. In addition, an expansion and strengthening of the existing evaluation system of colleges and universities has been proposed-a system instituted in 1983 by the Korean Council for University Education and modeled after the American accreditation system. 
The solutions discussed above are obviously quite important, for they will have a great impact on the survival of private institutions. However, several additional new problems have arisen. The government in Korea has always declared its support for the autonomy of private higher education. The government outwardly claims to stand for autonomous decision making by each institution on the adoption of the new division system, creating new professional schools, and so on. But, in practice, no institution has resisted such steps. The private institutions in Korea in their long history have grown so accustomed to accepting government suggestions as a way of protecting themselves from any potential unfair treatment from government. Such a pretense of autonomous uniform policy among private institutions extends throughout all parts of institutional management such as tuition policy, faculty recruitment, admissions, curriculum development, and internal governance. The authentic restructuring of private colleges and universities requires authentic autonomy of higher education institutions.

In July 1998, the government, which has sole authority over the establishment of higher education institutions, permanently shut down two private four-year institutions because of financial deficiency and poor academic management.

Another serious obstacle to restructuring private colleges and universities is the conflict between the private and the public sectors, and among the private institutions themselves. In practice, there are no substantial differences between public and private institutions in Korea, except that the public institutions are wholly government supported but the private ones are not. Institutions in both sectors are set up to be huge comprehensive "department store" institutions. They have not considered their location, the type of students enrolled, their resources, or, more importantly, their missions. It is high time for each institution to reconsider and reaffirm its role and reasons for existing. It is the right path for private institutions to follow to regain the public's trust. In addition, more systematic principles of management and governance should be developed in all corners of institutional life.

\section{Further Privatization in Japanese Higher Education?}

\author{
Akiyoshi Yonezawa \\ Akiyoshi Yonezawa is assistant professor in the Research Institute \\ for Higher Education at Hiroshima University. Address: 1-2-2 \\ Kagamiyama Higashi-Hiroshima 739-8512 Japan. E-mail: \\ <yonezawa@ipc.hiroshima-u.ac.jp>.
}

$\int_{\text {cen }}^{a}$ apan has one of the largest systems of private higher education in the world. More than 65 percent of high school graduates continue their studies; of these, over 70 percent are enrolled in private colleges and universities. Although private institutions receive about 10 percent of their financial resources from public funding, most public expenditure on higher education is allocated to the national and local public universities. The extensive private sector of Japanese higher education is currently threatening the status and viability of the national universities (all of which are public), which have been regarded as essential both for equality of access and the development of scientific research.

Within the national government, there are two different positions on higher education reform. On the one hand, the Ministry of Education has overall responsibility for the operation of the national universities and for the administration of local public and private universities. Therefore, the ministry is attempting to strengthen the quality assessment system for national and local public institutions as well as for private universities, in accordance with its bureaucratic orientation. On the other hand, other parts of government, such as the prime minister's office, respond more to the corporate sector's demands for privatization and deregulation of public services. This office, as well as others, recommends the privatization of national universities on the grounds that this would improve quality by introducing direct market competition. The argument for deregulation also emphasizes the necessity to make information on the quality of universities available for more informed consumer choice.

This controversy within the government complicates the discussion of quality assessment in Japanese higher education. Despite their lack of sophisticated understanding of the character of higher education, the other ministries have continuously pressed for the privatization of the national universities. In contrast, the Ministry of Education has persisted in trying to strengthen its formal assessment system to obtain necessary information for decision making in the al- 